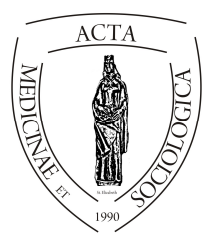

Acta Medicinae et

Sociologica (2020)

doi:

\title{
Néhány szempont a magyar egészségügyi ágazat problématérképének összeállításához
}

\author{
Paulikné Varga Barbara \\ tanársegéd, Debreceni Egyetem Egészségügyi Kar. 4400 Nyíregyháza, Sóstói u. 2-4.
}

\section{INFO}

Paulikné Varga Barbara

paulikne.barbara@foh.unideb.hu

\section{Keywords:}

health care system, organization, development, PEST analysis, strategy

\section{ABSTRACT}

\section{Kulcsszavak:} egészségügyi ellátórendszer, szervezet, fejlesztés, PEST analízis, stratégia
Abstract. Dysfunction of health care has been a hot issue recently. Financial and human resource problems have been perceived by many of us, although a pile of other interrelated problems also appears in this field. However, several of them could be improved with adequate management methods. In order to understand the changes previously carried out in health care, it is vital to get know the legislations documenting national and international tendencies. The multi-aspect research is based on documentations, comparative analysis and evaluation of statistics from the given field. Besides them, the financial system, the state's participation, and the service systems also need to be taken into consideration. Due to former reorganizations of health care, many different types of organizational structures connect with one another, and for profit and non profit organizations are interwoven. The complicated situation suggests that our research into this topic is rather timely. By revealing the health care systems of different countries, two basic tendencies seem to prevail. There are systems, in several states, which make cooperation easier, while there are differences, caused by historical events, whose abolition would serve everybody's interest.

Absztrakt: Napjainkban az egészségügy müködési zavarai mindennapi beszédtémák. Legtöbben csak az anyagi vagy a humánerő problémákat látják, holott egy problémahalmaz jellemzi ezt az ágazatot. Véleményem szerint ezek jelentős részét megfelelő menedzsment módszerekkel javítani lehetne. Az egészségügyben végbement változások bemutatásához a hazai és a nemzetközi trendeket dokumentáló jogszabályok ismerete nélkülözhetetlen. A több szempontú vizsgálat alapja az egyes ágazatokban keletkező dokumentációk, statisztikák összehasonlító elemzése, értékelése. Ezen túl a következőkre kell figyelni: vizsgálni kell a fi- 
nanszírozási rendszert, az állam részvételét és a szolgáltatási rendszereket. Az egészségügyi átszervezések kapcsán ma már sokféle szervezeti struktúra kapcsolódik össze, összefonódnak for- és nonprofit szervezetek, amelyek kutatása rendkívül aktuálissá teszi ezt a témát. A különböző országok egészségügyi rendszerének feltárása során kiderülhet, hogy két alapvető tendencia érvényesül. Vannak olyan, több államra jellemző rendszerek, amelyek megkönnyítik az együttmüködést, és vannak történelmi okokra visszavezethető eltérések, amelyek megszüntetése közös érdek lenne.

\section{Az egészségügyi rendszer vizsgálatának aktualitása}

Az egészségügyi ágazat az élet minden területéhez, szakaszához kapcsolódik, és a közbeszéd mindennapi témája a változás igényének a megfogalmazása. Már a gyermek fogantatásától kezdve folyamatos kapcsolatban vagyunk az egészségügyi ellátórendszerrel, a védőnői, a háziorvosi és az iskolaorvosi szolgáltatások kapcsán. Az ellátási rendszerben viszont a következő életszakaszokban arányeltolódás figyelhető meg. A szervezett és felügyelt folyamat a kisiskoláskorúak ellátása után megszakad, miközben a nagy szervezetben elvész az Ember, és a problémák sokasága jelentkezik. Az egészségügyi ágazat rendkívüli kiterjedtségét mutatja, hogy egyszerre van benne iparági és szolgáltatási szektor, elméleti és alkalmazott kutatás, üzleti és nonprofit szolgáltatás, állami és magán, nevezzük inkább üzleti finanszírozásnak. Az összetettsége miatt valójában komplex problémahalmaz képződött, amelynek korszerü kezelése megoldásra vár. Az egészségügyi átszervezések eredményeként ma már olyan sokféle szervezeti struktúra kapcsolódott össze, amelynek müködése egyszerre tudományos, szakpolitikai, igazgatási, szervezeti és vezetési feladatok ellátását igényli.

Fontos, eldöntendö kérdés, hogy milyen stratégia alapján történhet egy eredményes fejlesztés. Ehhez kapcsolódik a következő eldöntendő kérdés, kinek a felelőssége, ki készítse és vezesse ezt a változtatást? Valamennyi kérdésre itt nem tudunk válaszolni, de elkezdünk egy elemzési kísérletet, amely elsősorban a menedzsment eszköztárából merítve a klasszikus, a versenyszférában szerzett tapasztalatok alapján, elsősorban a változás és a stratégiai menedzsment módszerek adaptálásával új szempontú megközelítésre ad lehetöséget.

A problematika megvilágítására az alábbiakban elsősorban a PEST analízis módszerét alkalmazzuk, illetve ajánlást fogalmazunk meg a szervezetfejlesztés lehetséges útjainak a kiválasztásához és az egész egészségügyi rendszer vagy egyes területeinek korszerüsítéséhez. 


\section{Az egészségügy müködésének menedzsment szempontú elemzése}

Az egészségügyi rendszer müködéséről az Egészségügyi Világszervezet (WHO) 1946-ban megfogalmazott egy alkotmányt, amelyhez eddig 170 ország csatlakozott. Ebben elfogadták azokat az alapelveket, amelyek megfelelnek az évszázadok alatt megtartott gyógyítási etikának, de igyekeztek figyelembe venni a modern orvostudomány működtetésének a kívánalmait is (Baráth, 2008). Ezek közül néhány jelentösebb pontot fontos kiemelnünk:

- a kötelező szolidaritási elven múködő biztosítás keretében mindenki hozzájárul az alapvető és garantált minőségü egészségügyi szolgáltatáshoz,

- a szolgáltatási struktúra a valóságos egészségügyi szükségleteknek és a „fogyasztói” igényeknek is megfelel, a morbiditási, demográfiai változásokat rugalmasan kezeli,

- az eljárások hatásossága, hatékonysága megfelelö,

- a szolgáltatások rendszere, igénybevételük lehetősége és az egészségügyben elköltött közpénzek sorsa átlátható,

- az egészségügy finanszírozható rendszerben müködik, az egészségügyre fordított források hatékonysága nő.

Az elfogadott irányelveket a valóságban igen sokféleképpen értelmezték, és a megfogalmazásuk több mint fél évszázada aktuálisan él. Megvalósításuk azonban még mindig nem sikeres. A problémák feltárásához éppen ezért használjuk fel a PEST analízis módszerét, bár teljes részletességre itt most nem vállalkozhatunk. A klasszikus formájában kiterjed a politikai/jogi, a gazdasági - ami lehetőséget ad mind a makro, mind a mikro környezet jellemzésére is -, a társadalmi és a technológiai vizsgálatokra, és ma már kibővíthető az ökológiai, informatikai szempontokkal, ezáltal komplex megközelítésre ad módot. A kiemelt szempontok - úgy véljükalkalmasak az összefüggések megvilágítására.

\section{Az egészségügyi rendszer szakmapolitikai aspektusa}

Fontos tisztázni, hogy az államigazgatás szempontjából milyen elvek érvényesülnek. Amennyiben az egészségügyet a közjó fogalmához sorolja a politikai rendszer, úgy az állam aktívan rész vesz a müködtetésében. A közjó vagy a közszolgálat eszméje a felvilágosodás eszmerendszerében fogalmazódott meg, a tőkésállamokban már meggyökeresedett. A 19. századtól a legtöbb állam elfogadja, de különféle értelmezése és gyakorlata alakult ki. Abban azonban egység látszik, hogy az egészségügyet a nonprofit szektorhoz tartozónak mondják. A nonprofit, a közhasznú szolgáltatást az állam a beszedett adókból vagy az állampolgárok által befizetett biztosítási alapokból finanszírozza. A finanszírozás természetesen nagyban befolyásolja a müködést, a korszerüsítést és a gyógyítás minden fázisát, épp ezért vált a 19. század végétől alapkérdéssé. Európában az elmúlt évszázadban négy finanszírozási forma alakult ki. Az állami részvétel típusai: a Bismarck-i, a Szemaskó, a Beveridge és a Vegyes modell (Boncz, 2012). 
Magyarországon a szolidaritás elvü Bismarck-i egészségbiztosítási modell alapozta meg az egészségügyi rendszert. Ennek jellemzője, hogy nem az egész lakosság biztosított, a járulékbefizetés jövedelemarányos, az egészségügyi szolgáltatók köztulajdonban vannak, akik inkább együttmüködnek, mint versenyeznének. A magánbiztosítás kiegészíti az erős tb-alapú rendszert. Ma is alapvetően ez jellemző, de számos átalakuláson ment keresztül. 1948-1992 között a Szemaskó modell váltotta fel, amely szintén szolidaritás elvére hivatkozik, de a szocializmusban meghirdetett általános, mindenkit egyformán ellátó rendszer valójában nem tudta teljesíteni ígéretét. Elsősorban a minőségi fejlesztés maradt el, és ennek pótlására alakult ki a paraszolvencia szokása. Napjainkban már vegyes finanszírozású rendszer van kialakulóban, hiszen több területen érintkezik az állami és a magán egészségügyi szolgáltatás. A finanszírozásban a társadalombiztosítás mellett megjelentek a magánbiztosítók is, de ez a rendszer korántsem nevezhető kiforrottnak, hiszen számos ellentmondása abból fakad, hogy a különféle rendszerek úgy keverednek, hogy az átláthatóság sérül.

Az egészségügy jogi-igazgatási megközelítéséből következően, a közszolgálati szektor környezetét és müködését is kell értékelnünk. Antal-Mokos és mtársai közszolgálati szervezeteknek nevezi a „központi állami és helyi közigazgatást megtestesítő intézményeket, valamint mindazokat a szervezeteket, amelyek működését meghatározó részben állami vagy helyi önkormányzati költségvetésböl fedezik" (AntalMokos, Balaton, Drótos, \& Tari, 1997).

Max Weber szociológus a közigazgatással kapcsolatban azt vizsgálta, hogy a közigazgatás modern formája, a bürokrácia milyen jellemzőkkel bír. A bürokrácia Weber szerint nem feltétlenül tekinthető rossznak, de müködhet rosszul. A nem megfelelő szabályozás vagy a túlságosan mély hierarchia hatékonyságtól mentes müködést eredményezhet. Henry Mintzberg alapján az egészségügyi ellátó intézmények szakértői bürokráciaként értelmezhetőek, ahol fontos a komplex feladatellátás és a szakértők dominanciája. A fő jellemzők közé sorolható, hogy a szakértő (orvosok) munkája komplex, a megszerzett szaktudás lassabban változik, a szervezeten belül az orvosok autonómiája jelentős, a kollégáiktól viszonylag függetlenül, de a betegekkel szoros kapcsolatban állnak (Berde, 2015). A bürokratikus müködésre jellemző lassúság, rugalmatlanság a rosszul, diszfunkcionálisan müködő bürokráciák jellemvonásai, de ez nem kell, hogy feltétlenül így legyen. (Bodnár, Révész, \& Horváthné Varga Polyák)

\section{Közszolgálati szervezetek környezetelemzése}

Az üzleti szektortól eltérően müködik a közszolgálati intézmények értékesítési piaca, mert az intézmények által nyújtott szolgáltatás nem tekinthető klasszikus piaci árunak. Ebből következően elvileg nem érvényesül sem a fizetőképes kereslet változása, sem a piaci versenyre jellemző hatás. A közszolgálati szektor vevői, a potenciális haszonélvezők csak ráutaló magatartással (szolgáltatás igénybevételével vagy elutasításával) vagy érdekvédelmi szervezeteken keresztül tudják kinyilvánítani a szolgáltatásokkal szembeni véleményüket. Van egy viszonylag ritkábban alkalmazott opció, a politikai programok támogatása (pl. vizitdíj eltörlésével kapcsolatos kinyilatkoztatás).

A politikai környezet nagy befolyást gyakorol az egészségügyre. Esetünkben az országos kormánypolitika és a települési önkormányzatok által képviselt helyi poli- 
tika is hatással van az egészségügyi szervezetek működésére. Korlátozó tényezőnek minősül a szolgáltatások kvázi ingyenessége, valamint az intézmények területi ellátási kötelezettsége miatt kialakuló földrajzi korlátja. A közszolgálati szektorban különös formában van jelen a versenyhelyzet, számos esetben nem is létezik. Ebben a környezetben viszont említésre méltó, hogy az eléggé korlátozott piaci mozgástérben versenytársként a közszolgálatok mellett a magánszervezetek jelentik a legnagyobb konkurenciát.

A közszolgálati szervezetek tudományos-technikai környezete alapvetően a közösségi szolgáltatások előállításában szerepet játszó technikák, technológiák beszerzésére irányul, amelyek jelentős része az utóbbi másfél évtizedben Európai Uniós pályázati forrásból volt finanszírozva. A gyógyításban mára már nélkülözhetetlen a korszerü orvosi diagnosztikai müszerek megléte, információk gyüjtése és feldolgozása, ami az egészségügyi intézmények alapvető feladatainak ellátása során keletkezik. Utóbbi feladat miatt az információtechnológia kiemelt környezeti tényezőnek minősül az egészségügyi intézmények életében, de a lehetőségek még messze nincsenek kihasználva a közszolgálati szervezetekben. A számítógépek megjelenése alapvetően megváltoztatta az addig egyszerünek tekinthető egészségügyi ellátást. A betegkartonok egyszerü szerkezete és vezetése össze sem hasonlítható azzal az adatmennyiséggel, amely a mai finanszírozási rendszerben alapvetően jelentendő adatnak tekintendő. A digitalizáció térnyerésének látványos eredménye, hogy ez alapján a mai Elektronikus Egészségügyi Szolgáltatási Térben a beteg ellátása érdekében szinte bárhol elérhetővé váltak az adataink. Az egészségügyi dokumentumok, adatok elérhetősége megrémíti az egészségügyi dolgozókat, egy részük nehezen éli meg ezt a fajta változást és az ebből adódó ismeretek megszerzésének a kényszerét. Másrészt az informatikai rendszerek egyfajta minőségi munkára kényszerítik a dolgozókat, hiszen az elvégzett tevékenység hatása és hatékonysága ellenőrizhetővé válik. Az adatok széleskörü kereshetővé válásával egy új szemlélet jelent meg.

\section{Az egészségügyi ellátórendszer fogalma, müködése}

Ez az a témakör, amelyről a legtöbb vitát folytatják, és amiről szívesen mondják, hogy ez az egészségügy szervezetének a fejlesztéséről szól. Ez azonban csak a látszat, hiszen nem a teljes egészségügyről, hanem arról a finanszírozással szorosan összefonódó szervezeti formáról szól, amelyekben az orvos-beteg kapcsolatok megvalósulnak, ahol a gyógyítás vagy a gondozás (preventív vagy korrekciós tevékenységek, stb.) különböző szintjei létrejönnek. Kialakultak az idők folyamán olyan ellátási szintek, amelyek összehangolása, irányítása, fejlesztése valóban a leginkább szemléletessé teszi mindazon problémákat, amelyek az egész ágazatot jellemzik.

A magyar egészségügyi ellátórendszer a WHO ajánlásának megfelelően alapellátásra és szakellátásra különül el. A szakellátás két területe a járó- és fekvőbeteg szakellátás. A szürővizsgálaton résztvevőknek és a betegeknek ezeken a szinteken szükséges eligazodniuk.

Az egészségügyi alapellátás feladata a hosszú távú, személyes kapcsolaton alapuló, a beteg nemétől, korától és betegsége természetétől függetlenül a beteg lakóhelyén vagy annak közelében végzett egészségügyi ellátás. Az alapellátáshoz közvetlenül a háziorvosi, a fogorvosi, a védőnői és az iskolaorvosi szolgálat tartozik. Az állam a közszolgálati feladatok ellátását jellemzően vállalkozói formában müködő 
szolgáltatóknak finanszírozza. A háziorvosi ellátás alapvetően kétszereplős szervezetekben valósul meg. A kialakított szervezet a lineáris szervezeti struktúra elemeit ölti magára, és felemás gazdálkodási szervezetnek tekinthető. A háziorvosi szolgálatok általánosságban olyan for-profit szervezetek, amelyek közösségi tulajdonnal gazdálkodnak. Az egészségügyi szolgáltatók közül a háziorvosi szolgálatok számára engedélyezték először a 2000. évi II. törvény rendelkezése alapján az egyéni vállalkozói vagy gazdálkodó szervezeti formában megvalósuló müködést. Ez a müködési forma azzal jár együtt, hogy a praxisnak kell kigazdálkodni a müködésükhöz szükséges feltételrendszerét, ezért például csak a nagyon nyereséges háziorvosi szolgálatok engedhetik meg maguknak, hogy ápolón kívül adminisztrátort is alkalmazzanak. Az 1996-os ágyszám-törvény, majd a 2006. évi ellátás fejlesztési törvény hatására közel 21 ezer ágyat vontak ki a fekvőbeteg ellátásból (Ágoston, és mtsai., 2009). Ezen kapacitáshiány kompenzálására hozták létre 1996-ban az otthoni szakápolás szervezeteit, amely háziorvos elrendelése alapján valósulhat meg, de egyéb szakellátásnak minősül. 2004-től létrejött az otthoni hospice ellátás. A szakápolói szolgálat otthoni környezetben, személyre szabottan, szakszerü ápolást nyújt a háziorvos szakmai felügyelete mellett. A jól müködő otthoni ellátási rendszerrel valóban csökkenthető a kórházak túlterheltsége, de a gyakorlat számos új problémát hoz a felszínre. Az idősödő társadalomban egyre inkább összefonódik a szociális gondozás és az otthoni betegápolás, amelyet részben egészségügyi, másrészt önkormányzati feladatként látnak el, és megállapítható, hogy egyre több a piaci alapon müködtetett ellátó-gondozó intézmény.

A szakellátás klasszikus értelemben két részterületre különíthető el a járó- és fekvőbeteg szakellátásra. A járóbeteg ellátás keretein belül alapvetően orvosi beutalóval érkezhetnek a betegek ambuláns ellátására, szürővizsgálatokra, vagy a krónikus betegségek gondozására. Ennek a szintnek a fejlesztése komoly minőségi eredményeket hozhatna, egyelőre azonban sem a humánerő ellátása, sem a kapacitása nem éri el a kívánt szintet.

A fekvőbeteg ellátás elsősorban a kórházakban valósul meg, amelyek mára bonyolult és „magasan tagolt” bürokratikus szervezetekké váltak, amelyek irányítása, összehangolása rendkívül nehéz feladat és finanszírozása problémák tömegét hozza magával. Sokat mond Cristie Hofner megállapítása, aki szerint „A jelenlegi állapot megőrzése kockázatosabb, mint a változás” (Baráth, 2008). A szervezetek, jelen esetben a kórházak alkalmazkodóképességének elérése és fejlesztése érdekében a szándékos és céltudatos változtatásokkal képesek lennének a kórházak reagálni a környezet és a saját müködésük által generált kihívásokra (Polónyi, 2015).

Ezekkel a szintekkel azonban még nem teljes az egészségügyi ellátórendszer, és ez mutatja, hogy a teljes struktúrának legfontosabb, de nem teljes elemei a fenti szolgáltatók. Elég megemlíteni azokat a szakszolgálatokat, amelyek valamennyi szint müködéséhez ma már elengedhetetlenek. Ilyenek elsősorban a labor, a képalkotói diagnosztikai, az informatika szolgáltatások.

$\mathrm{Az}$ egészségügyi ágazat korszerüsítésének elengedhetetlen részét képezik más társadalmi alrendszerek, amelyeknek vannak ide kapcsolódó szervezetei. Ilyen az oktatás, a kutatás intézményei, a népegészségügyi szolgálatok müködése, és nem utolsósorban az egyre inkább egészségiparnak tekintett gyógyszergyártás, segédeszközök gyártása és forgalmazása. 


\section{A néhány kiemelt társadalmi vizsgálati szempont}

\section{Milyen a humánerőforrás gazdálkodás, fejlesztés?}

Sajnálatosan nagy a szakember hiány, alacsony az anyagi megbecsülés, hiányosak vagy nem állnak rendelkezésre a megfelelő müködési feltételek, stb. Ezek indokolják egy átfogó felmérés készítését, amelyben nemcsak a hiányosságok feltérképezése, hanem az elhivatottság meglétének vagy hiányosságainak mértékét is megtudhatnánk. Ehhez szempontokat ad Horváth Zsuzsanna - Hollósy-Vadász Gábor: Közszolgálati motivációs modellek tesztelése útelemzéssel munkája. Az általuk kidolgozott Közszolgálati motiváció=Public Service Motivation = azaz a PSM modell a nemzetközi és hazai közszolgálati dolgozók elégedettség vizsgálatához az alábbi szempontokat ajánlja:

- közszolgálati motiváció (jelentése szerint a munkavállalókat arra ösztönzi, hogy olyan közszolgálati szervezeteknél dolgozzanak, melyek küldetésének középpontjában a közösség áll);

- a munka társadalmi hatásainak észlelése (a munkavállaló által végzett munka milyen hatással van másokra és a társadalomra, illetve a munkavállaló ezt hogyan észleli).

- a magas jövedelem fontossága (a munkavállaló fontosnak tartja-e, hogy a munkájával magas jövedelemre tegyen szert);

- munkahelyi szervezeti elkötelezettség (egyéni erő, ami megerősíti a személy szervezet iránti lojalitását; a továbbiakban szervezeti elkötelezettség). Ezt a vizsgálatot a szakszemélyzet minden szintjén érdemes lenne egy reprezentatív felmérés keretében elvégezni, egyúttal a területi eredményeket is elemezni. (Horváth \& Hollósy-Vadász, 2019)

\section{Van-e stratégiája az egészségügyi ágazatnak?}

Felvetődik a klasszikus menedzsment feladatok közül, hogy vajon van-e valójában stratégiája az egészségügyi ágazatnak? Feltételezzük, hogy nincs átfogó, hosszú távú stratégia, vagy legalábbis nem teljes. Ebböl adódik a további kérdés, kinek kellene elkészítenie?

Erre is lehet menedzsment tudományból és gyakorlatból válaszokat keresni. Elsősorban a New Public Management szemléletének az érvényesítésével (Rosta, 2012).

Minden eddigi vizsgált szempontunk alapján a nagy kihívás az eredményes szervezeti müködés elérése. Ennek érdekében nagyon fontos szerepe van a megfelelően kialakított és müködtetett szervezeteknek, koordinációs mechanizmusoknak. Említhetünk jó példaként nemzetközi szervezetfejlesztést, amely egy nagy mátrixon belül többféle szintü és szerkezetü struktúrát képes koordinálni (Csiki, 2018).

\section{A szervezetfejlesztés definíciós problémái az egészségügyben}

A fenti megállapítások alapján látható, hogy nehéz ma a magyar egészségügy szervezeti formáját meghatározni, hiszen valamennyi, a vezetéstudományban ismert szervezeti formát megtalálhatjuk az egyes szakterületek müködésében. Az Európai Unió egészségügyi szervezeteinek a tipológiájánál elsősorban abból indulnak ki, hogy milyen a centralizáció foka, miközben az általunk is megjelölt szakterületeket 
vették az intézményi, az irányítási, a tervezési, stb. vizsgálatokban iránymutatónak. A magyar irányítási rendszer - annak ellenére, hogy legtöbbször centralizált volt elég gyakran változott. Gondoljunk arra, hogy hol önkormányzati, hol holdingirányítású kórházaink voltak, de nem volt a konszernforma bevezetésére kezdeményezés, amelyben az alárendelö és egyenrangú viszonyok megférnek, és amelyben a mátrix szervezet müködtetésének a formája is összeilleszthető (tevékenység típusú és/vagy terület típusú müködés, stb.)

A vizsgálati aspektusokat - noha nem teljes körüek - elég sokrétünek tartva, elég szembetünően mutatja, hogy egy jelentős szempont kimaradt. Nevezetesen annak értelmezése hogyan valósíthatóak meg a menedzsment feladatok az egészségügyi ágazat szervezetének korszerüsítésében, irányításában, vezetésében, koordinációjában, ellenőrzésében, stb. A részek kidolgozására többen vállalkoztak, de, ha nincs jó stratégiája, a részek nem adják meg az egész felépítés stabilitását. Az utóbbi években több kiváló menedzsment szemléletü elemzés is megjelent, például Dózsa Csaba több tanulmánya az egészségügyi struktúra átalakításáról.

Összegzésként most azonban azt idézem, amelyben a teljes ágazatra elfogadható koncepciót foglalta össze Baráth Lajos (2008). Szerinte a megoldást az jelentené, ha a mereven hierarchikus rendszert a mátrix szervezet megoldási variánsai váltanák fel, amelyeken belül a funkcionális szervezeti elemek jellemzőek. Szerinte a kórházi struktúra korszerüsítésének legfontosabb lépése a bürokratikus és túlzottan „magas”, hierarchikus kórházi szervezeteket kevésbé bürokratikus „laposabb” szervezetté átalakítani. Elképzelése alapján ezzel csökkenteni lehetne az adminisztrációt, a dolgozói teamek elszigetelődését, valamint a döntési jogkörök centralizáltságát. A korszerütlen szervezeti struktúra átalakítása a betegellátás érdekében és a célravezető munkafolyamatok végzése miatt elkerülhetetlen, s ezáltal a szervezet hatékony müködése szempontjából fontos kezdeményezések gyorsabban érvényesülhetnének.

\section{Összefoglalás}

Az egészségügyi szervezetek környezetét vizsgálva megállapíthatjuk, hogy az rendkívül komplex. A környezeti szegmensek eltérö értéküek és más-más magatartásmintát képviselnek. A különböző érdekek és elvárások nehezen rendezhetőek össze. A mindenkori nemzetgazdaság állapota elsősorban magas korlátokat, de nagy lehetőségeket is hordoz magában az ágazat mozgástere szempontjából. Az átrendeződés alapvetően financiális alapú, de mégis magába foglal bizonyos vezetési-szervezési feladatokat, amelyek megoldása az egyes szolgáltatók esetében más-más szemléletet kíván.

Jelen tanulmányban elsősorban a szervezeti szintü változások indokoltságát szerettük volna alátámasztani (Elbert, Karoliny, Farkas, \& Poór , 1999). Úgy véljük, hogy a szándékos és céltudatos változtatásokkal a szervezet képes reagálni a környezet és a saját müködése által generált kihívásokra, s ezzel a szervezet alkalmazkodóképességének fejlesztése és az egyének viselkedésében bekövetkező változások elérhetővé céllá válhatnak. Ugyanakkor minden változás megtervezése és bevezetése konfliktusokat hordoz magában, és ezekre a konfliktusokra valamilyen feloldást kell keresni. A Kurt Lewin által erőtér-analízisnek elnevezett modell a változás során a 
befolyásoló tényezőket azonosítja, amelyek lehetnek hajtó-, és fékezőerők, valamint az erők által egyensúlyban tartott szervezet. A hajtóerők erősödését és a fékezőerők gyengülését tudatosan is befolyásolhatja a menedzsment, ami segítheti egy jól müködő szervezet, egy társadalmilag determinált alrendszer müködtetését.

\section{Irodalomjegyzék}

1. Ágoston, I., Vas, G., Imhof, G., Endrei, D., Betlehem, J., \& Boncz, I. (2009). A magyar egészségügyi kapacitások törvényi szabályozásainak változásai. Egészségügyi Gazdasági szemle, 3-7.

2. Antal-Mokos, Z., Balaton, K., Drótos, G., \& Tari, E. (1997). Stratégia és szervezet. Budapest: Közgazdasági és Jogi Könyvkiadó.

3. Baráth, L. (2008). Az egészségügy és a kórház, mint szervezet kihívásai a XXI. században. Egészségügyi Gazdasági Szemle, 10-12.

4. Berde, C. (2015). Szakértői szervezetek autonómiája. TAYLOR: GAZDÁLKODÁS- ÉS SZERVEZÉSTUDOMÁNYI FOLYÓIRAT, 36-42.

5. Bodnár, V., Révész, É., \& Horváthné Varga Polyák, C. (dátum nélk.). Kontorlling az egészségügyben. TÁMOP : E-book.

6. Boncz, I. (2012). Egészségügyi finanszírozási, menedzsment és minőségbiztosítási alapismeretek. Budapest: Medicina Könyvkiadó Zrt.

7. Csiki, G. (2018. július 31.). Portfolio.hu. Forrás: A magyar, aki Európa egészségügyét alakítja: https://www.portfolio.hu/impakt/20180731/a-magyar-akieuropa-egeszsegugyet-alakitja-292732

8. Elbert, N., Karoliny, M., Farkas, F., \& Poór , J. (1999). Személyzeti/emberi erőforrás menedzsment kézikönyv. Budapest: Közgazdasági és Jogi Könyvkiadó.

9. Horváth, Z., \& Hollósy-Vadász, G. (2019). Közsszolgálati motivációs modellek tesztelése útelemzéssel. Statisztikai szemle, 269-287.

10. Polónyi, I. (2015). Változtatásmenedzsment - a minőségügyi rendszerek bevezetése és fejlesztése kapcsán - az egészségügyben. Magyar Minőség, 49-61.

11. Rosta, M. (2012). Innováció, adaptáció és imitáció az új közszolgálati menedzsment. Budapest: Aula Kiadó.

Az egészségügyi ágazat reformjának eddigi legfontosabb jogszabályai:1997. évi CLIV. törvény az egészségügyről

2000. évi II. törvény az önálló orvosi tevékenységről

2015. évi CXXIII. törvény az egészségügyi alapellátásról

43/1999. (III.3) Korm. rendelet Az egészségügyi szolgáltatások Egészségbiztosítási Alapból történő finanszírozásának részletes szabályairól 6/2003. (VII. 15.) Korm. rendelet Az egészségügyi szolgáltatás gyakorlásának általános feltételeiröl, valamint a müködési engedélyezési eljárásról

39/2016. (XII. 21.) EMMI rendelet EMMI rendelet az Elektronikus Egészségügyi Szolgáltatási Térrel kapcsolatos részletes szabályokról

43/2003. ESzCsM r. a gyógyintézetek müködési rendjéről, illetve a szakmai vezető testületéről 